\title{
Restoration Study of Microorganisms in Lake Water Purification
}

\author{
Fang Yang, Rui Zhu \\ Hebei Electric Power Design \& Research Institute, Shijiazhuang, China \\ Email: zhurui423@163.com, bdsunjinxu@163.com
}

Received 2013

\begin{abstract}
We screened the bacteria with restoration and purification functions in lake water and found that, Bacillus subtilis had the highest water purification ability. Photosynthetic bacteria, lactobacillus bacteria, nitrifying bacteria and oligotrophic bacteria also showed different levels of lake water purification and restoration. $\mathrm{L}_{18} 7^{3}$ orthogonal experiments were designed to optimize the ratio of complex agents to get the best ratio of various bacteria as $10 \mathrm{~g} / \mathrm{L}$ Bacillus subtilis, $2 \mathrm{~g} / \mathrm{L}$ photosynthetic bacteria, $0.8 \mathrm{~g} / \mathrm{L}$ lactobacillus, $0.6 \mathrm{~g} / \mathrm{L}$ nitrifying bacteria $1,0.4 \mathrm{~g} / \mathrm{L}$ nitrifying bacteria 2 and $0.6 \mathrm{~g} / \mathrm{L}$ oligotrophic bacteria. When lake water was purified for $30 \mathrm{~d}$ under this ratio, total phosphorus content decreased $85.90 \%$, total nitrogen content decreased $70.96 \%$, and COD value decreased $81.19 \%$.
\end{abstract}

Keywords: Water Purification Microorganisms; COD; Total Phosphorus; Total Nitrogen

\section{Introduction}

Due to the impacts of human life and pollution, nitrogen, large amounts of phosphorus and other nutrients entered into the lake [1]. This causes rapid growth of algae and other plankton, decreased dissolved oxygen in water bodies, deteriorated water quality, and massive death of fish and other organisms; this phenomenon is known as water bloom of lake water. The major components that cause lake water bloom were phosphorus, nitrogen and organic carbon [2]. The microbial water purification and restoration rely mainly on microbial metabolism for the purpose of deaminase, dephosphorization and carbon transfer to purify and restore water bodies [3].

Lake water is generally hydrostatic water and more prone to eutrophication, which is further exacerbated by the plant nutrients imputs from industrial wastewater, domestic sewage and agricultural runoff. It is hard to solve the eutrophication of lake solely relying on the selfpurification of lake water, and lake eutrophication is urgent to be solved [4,5].

In this study, we screened the bacteria strains with restoration and purification functions in lake water and studied the ratio of bacteria agents in order to obtain the microbial agents with significant purification and restoration effects on lake water.

\section{Materials and Equipment}

\subsection{Materials and Strains}

Lake water was obtained from Hengshui Lake at Nation- al Wetland Nature Reserve; Bacillus subtilis, Photosynthetic bacteria, Lactobacillus bacteria, Nitrifying bacteria and Oligotrophic bacteria were preserved by our laboratory.

\subsection{Instruments}

Multi-parameter water quality analyzer was purchased from Hualian Technology Co., Ltd. (5b-6c).

\section{Methods}

\subsection{Determination of the Total Number of Bacteria}

The number of bacteria was determined by plate counting method.

\subsection{Determination of Total Nitrogen}

Total nitrogen was determined as described in "Alkaline potassium persulfate digestion ultraviolet spectrophotometry determination of water quality total nitrogen" (GB11894-89).

\subsection{Determination of Total Phosphorus}

Total phosphorus was determined as described in "Ammonium molybdate spectrophotometry determination of water quality total phosphorus” (GB 11893-89).

\subsection{Determination of COD}

$\mathrm{COD}_{\mathrm{Mn}}$ was determined as described in "protein-per- 
manganate index determination” (GB11892-89).

\subsection{Microorganism Culture}

1) Seed culture media

Seed culture media for Bacillus subtilis, photosynthetic bacteria, lactobacillus bacteria, nitrifying bacteria and were beef extract peptone medium.

2) Proliferation medium (g/L): glucose 1, yeast extract 0.7, peptone 1, $\left(\mathrm{NH}_{4}\right)_{2} \mathrm{SO}_{4} 0.2, \mathrm{MgSO}_{4} \cdot 7 \mathrm{H}_{2} \mathrm{O} 0.2, \mathrm{KH}_{2} \mathrm{PO}_{4}$ 1 , and agar $18 \mathrm{~g}, \mathrm{pH} 7.2$.

\subsection{Screening of Lake Water Restoration and Purification Bacteria}

According to information reported in literature, microorganisms with water restoration and purification functions, Bacillus subtilis, photosynthetic bacteria, lactobacillus bacteria, nitrifying bacteria 1, nitrifying bacteria 2 and oligotrophic bacteria, were selected, and total phosphorus, total nitrogen and COD value in lake water were measured. Lake water from same position was selected and aliquoted into 7 1L-flasks. The adding amount of microorganisms were: $6 \mathrm{~g} / \mathrm{L}$ Bacillus subtilis, $2 \mathrm{~g} / \mathrm{L}$ photosynthetic bacteria, $0.4 \mathrm{~g} / \mathrm{L}$ lactobacillus, $0.2 \mathrm{~g} / \mathrm{L}$ nitrifying bacteria $1,0.2 \mathrm{~g} / \mathrm{L}$ nitrifying bacteria 2 , and $0.4 \mathrm{~g} / \mathrm{L}$ oligotrophic bacteria, with plain water as control. Different water indicators in lake water were determined $20 \mathrm{~d}$ after adding agents, and the measure temperature was $20^{\circ} \mathrm{C}$.

\subsection{Design of Orthogonal Experiment for Complex Agents Ratio}

According to relevant experimental reports and conventional value, orthogonal experiments were preformed mainly using Bacillus subtilis with five other supplemental microorganisms, each containing three concentrations $\left(\mathrm{L}_{18} 7^{3}\right)$. The level of orthogonal design factors was shown in Table 1.

\section{Results and Discussion}

\subsection{Screening of Lake Water Restoration and Purification Bacteria}

According to relevant literature, six kinds of microorganisms with lake water purification and restoration ability were selected for pilot study. Related indicators were measured, and the results were shown in Figure 1.

As shown in Figure 1, $20 \mathrm{~d}$ after adding agents, total phosphorus, total nitrogen and COD values in each water sample revealed that all six bacteria had different levels of water purification and restoration ability. Bacillus subtilis had strongest purification ability of total phosphorus purification, lactobacillus had higher ability of nitrogen purification, and photosynthetic bacteria higher ability
Table 1. $\mathrm{L}_{18}\left(3^{7}\right)$ orthogonal experimental design.

\begin{tabular}{cccccccc}
\hline & \multicolumn{7}{c}{ Factors } \\
\cline { 2 - 8 } & $\mathrm{A}(\mathrm{g} / \mathrm{L})$ & $\mathrm{B}(\mathrm{g} / \mathrm{L})$ & $\mathrm{C}(\mathrm{g} / \mathrm{L})$ & $\mathrm{D}(\mathrm{g} / \mathrm{L})$ & $\mathrm{E}(\mathrm{g} / \mathrm{L})$ & $\mathrm{F}(\mathrm{g} / \mathrm{L})$ & $\mathrm{G}$ \\
\hline 1 & 6 & 1 & 0.4 & 0.2 & 0.2 & 0.4 & 1 \\
2 & 8 & 2 & 0.6 & 0.4 & 0.4 & 0.6 & 2 \\
3 & 10 & 3 & 0.8 & 0.6 & 0.6 & 0.8 & 3 \\
\hline
\end{tabular}

Notes: A: Bacillus subtilis; B: Photosynthetic bacteria; C: Lactic acid bacteria; D: Nitrobacteria 1; E: Nitrobacteria 2; F: Oligotrophic bacteria; G: Error.

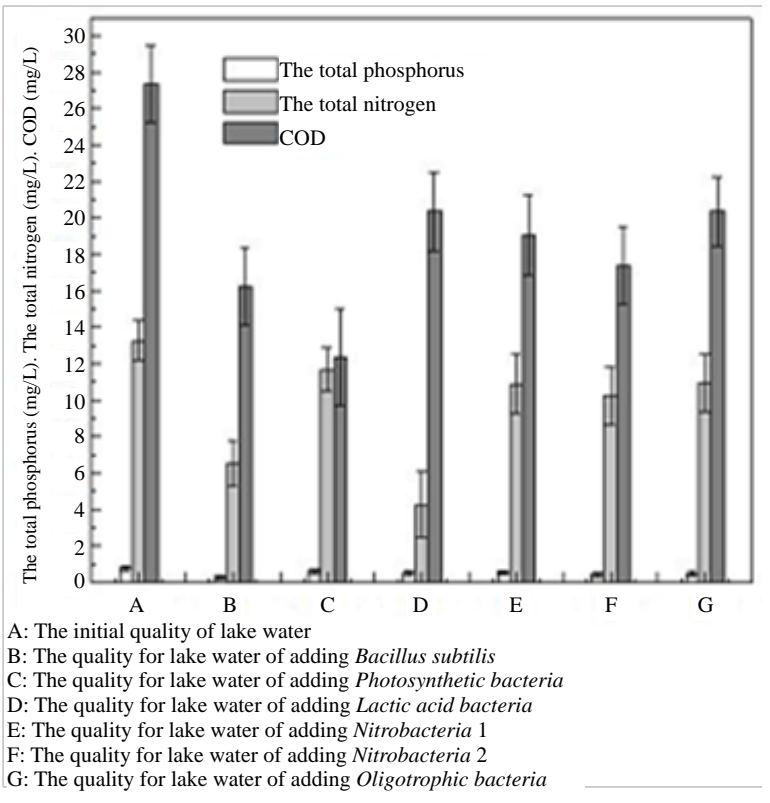

Figure 1. The purifying and repairing bacteria screening for lake water.

of COD purification. Comprehensive analysis of three measured indicators to compare to the purification ability of each bacterium showed that Bacillus subtilis group exhibited strongest water purification capability. According to the purification characteristics of each bacterium, we used a complex agent based on Bacillus subtilis with five other supplemental bacteria as purification agents for studies.

\subsection{Ratio of Complex Agent}

Using COD value as $\mathrm{L}_{18} 7^{3}$ orthogonal experiment results, complex agent was added and the results were determined $20 \mathrm{~d}$ later, as shown in Table 2.

As shown in Tables 2 and 3, the ratio difference of various agents had high impacts on the measured COD values. Among each agent ratio, Bacillus subtilis and nitrifying bacteria displayed highly significant impacts, and lactobacillus and oligotrophic bacteria had significant impacts. According to the F value, the order of impacts of each bacteria on COD was: Bacillus subtilis > 
Table 2. Visual analysis for $L_{18}\left(3^{7}\right)$ orthogonal experimental design.

\begin{tabular}{|c|c|c|c|c|c|c|c|c|}
\hline \multirow{2}{*}{$\begin{array}{l}\text { Number } \\
\text { of test }\end{array}$} & \multicolumn{7}{|c|}{ Factors } & \multirow{2}{*}{$\begin{array}{c}\mathrm{COD} \\
(\mathrm{mg} / \mathrm{L})\end{array}$} \\
\hline & A & B & $\mathrm{C}$ & $\mathrm{D}$ & E & F & G & \\
\hline 1 & 1 & 1 & 1 & 1 & 1 & 1 & 1 & 16.91 \\
\hline 2 & 1 & 2 & 2 & 2 & 2 & 2 & 2 & 17.32 \\
\hline 3 & 1 & 3 & 3 & 3 & 3 & 3 & 3 & 15.25 \\
\hline 4 & 2 & 1 & 1 & 2 & 2 & 3 & 3 & 13.05 \\
\hline 5 & 2 & 2 & 2 & 3 & 3 & 1 & 1 & 11.25 \\
\hline 6 & 2 & 3 & 3 & 1 & 1 & 2 & 2 & 10.85 \\
\hline 7 & 3 & 1 & 2 & 1 & 3 & 2 & 3 & 7.22 \\
\hline 8 & 3 & 2 & 3 & 2 & 1 & 3 & 1 & 7.35 \\
\hline 9 & 3 & 3 & 1 & 3 & 2 & 1 & 2 & 7.38 \\
\hline 10 & 1 & 1 & 3 & 3 & 2 & 2 & 1 & 5.36 \\
\hline 11 & 1 & 2 & 1 & 1 & 3 & 3 & 2 & 7.9 \\
\hline 12 & 1 & 3 & 2 & 2 & 1 & 1 & 3 & 9.53 \\
\hline 13 & 2 & 1 & 2 & 3 & 1 & 3 & 2 & 7.52 \\
\hline 14 & 2 & 2 & 3 & 1 & 2 & 1 & 3 & 7.9 \\
\hline 15 & 2 & 3 & 1 & 2 & 3 & 2 & 1 & 8.82 \\
\hline 16 & 3 & 1 & 3 & 2 & 3 & 1 & 2 & 7.65 \\
\hline 17 & 3 & 2 & 1 & 3 & 1 & 2 & 3 & 5.27 \\
\hline 18 & 3 & 3 & 2 & 1 & 2 & 3 & 1 & 6.81 \\
\hline $\mathrm{K}_{1}$ & 12.05 & 9.62 & 9.89 & 9.60 & 9.57 & 10.10 & 9.42 & \\
\hline $\mathrm{K}_{2}$ & 9.90 & 9.50 & 9.94 & 10.62 & 9.64 & 9.14 & 9.77 & \\
\hline $\mathrm{K}_{3}$ & 6.95 & 9.77 & 9.06 & 8.67 & 9.68 & 9.65 & 9.70 & \\
\hline $\mathrm{R}$ & 5.10 & 0.28 & 0.88 & 1.95 & 0.11 & 0.96 & 0.35 & \\
\hline
\end{tabular}

Table 3. The variance analysis for mycelium production.

\begin{tabular}{cccccc}
\hline Factors & $\begin{array}{c}\text { The square } \\
\text { of deviations }\end{array}$ & $\begin{array}{c}\text { Free } \\
\text { degree }\end{array}$ & $\mathrm{F}$ & $\begin{array}{c}\text { The critical } \\
\text { value of } \mathrm{F}\end{array}$ & Significance \\
\hline $\mathrm{A}$ & 78.627 & 2 & 2125.054 & 19.000 & $* * * *$ \\
$\mathrm{~B}$ & 0.228 & 2 & 6.162 & 19.000 & \\
$\mathrm{C}$ & 2.933 & 2 & 79.270 & 19.000 & $*$ \\
D & 11.397 & 2 & 308.027 & 19.000 & $* *$ \\
E & 0.037 & 2 & 1.000 & 19.000 & \\
F & 2.787 & 2 & 75.324 & 19.000 & $*$ \\
G & 0.423 & 2 & 11.432 & 19.000 & \\
Error & 0.04 & 2 & & & \\
\hline
\end{tabular}

nitrifying bacteria $1>$ lactobacillus $>$ oligotrophic bacteria $>$ photosynthetic bacteria $>$ nitrifying bacteria 2 . According to the $\mathrm{K}$ value, the best bacteria combination was: $\mathrm{A}_{3} \mathrm{~B}_{2} \mathrm{C}_{3} \mathrm{D}_{3} \mathrm{E}_{2} \mathrm{~F}_{2}$, i.e. $10 \mathrm{~g} / \mathrm{L}$ Bacillus subtilis, $2 \mathrm{~g} / \mathrm{L}$ photosynthetic bacteria, $0.8 \mathrm{~g} / \mathrm{L}$ lactobacillus, $0.6 \mathrm{~g} / \mathrm{L}$ nitrify- ing bacteria 1, $0.4 \mathrm{~g} / \mathrm{L}$ nitrifying bacteria 2, and $0.6 \mathrm{~g} / \mathrm{L}$ oligotrophic bacteria. It is proved by experiments that under this condition, the COD value at $20 \mathrm{~d}$ after adding complex agents was $5.13 \mathrm{mg} / \mathrm{L}$, which was lower than the minimal value in orthogonal experimental design. Comparing with the COD value in original lake water sample, the number decreased $81.15 \%$.

\subsection{The Impact of Complex Agent on Total Phosphorus Reduction}

Complex agent in optimal ratio was added into lake water, total phosphorus content in lake water was measured every 5 d. The results were shown in Figure 2.

As shown in Figure 2, after complex agent in optimal ratio was added into lake water, the total phosphorus content in lake water quickly declined in $10 \mathrm{~d}$. Between $10 \mathrm{~d}$ and $30 \mathrm{~d}$, the total phosphorus content decreased, but in a slow rate. Within the experimental period, the lowest total phosphorus content was observed at $30 \mathrm{~d}$, with the minimal value of $0.11 \mathrm{mg} / \mathrm{L}$ and the relative reduction of $85.90 \%$, indicating that addition of complex agent in this ratio can effectively reduce the phosphorus content in lake water.

\subsection{The Impact of Complex Agent on Total Nitrogen Reduction}

Complex agent in optimal ratio was added into lake water, total nitrogen content in lake water was measured every 5 d. The results were shown in Figure 3.

As shown in Figure 3, after complex agent in optimal ratio was added into lake water, the total nitrogen content in lake water quickly declined in $20 \mathrm{~d}$ then slowly decreased. Within the experimental period, the lowest total nitrogen content was observed at $30 \mathrm{~d}$, with the minimal value of $4.03 \mathrm{mg} / \mathrm{L}$ and the relative reduction of $70.96 \%$,

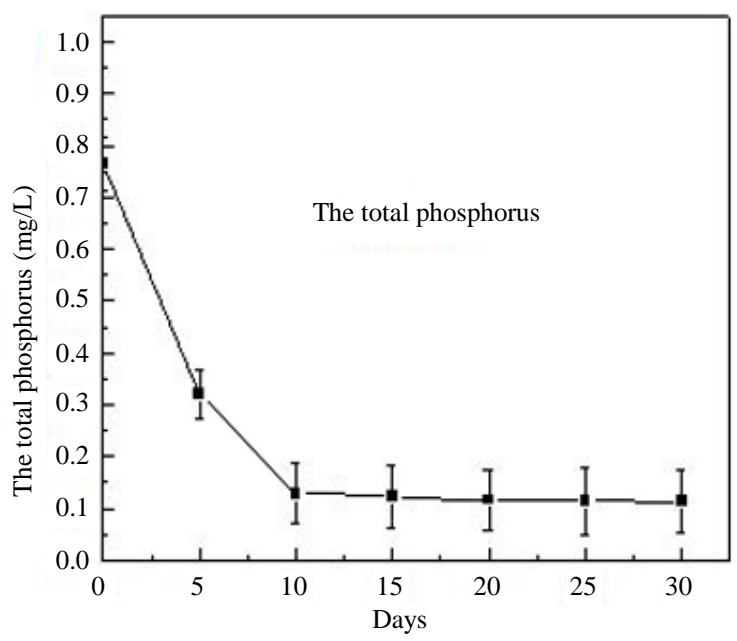

Figure 2. The complex agent effect to total phosphorus of lake water. 
indicating that the complex agent in this ratio had good effects on reducing nitrogen content in lake water.

\subsection{The Impact of Complex Agent on COD Value}

Complex agent in optimal ratio was added into lake water, COD value in lake water was measured every $5 \mathrm{~d}$. The results were shown in Figure 4.

As shown in Figure 4, when adding complex agent in optimal ratio, the COD value showed highest reduction extent in the first $20 \mathrm{~d}$, which may be because the better effects and higher activity of complex agent during this period. After $20 \mathrm{~d}$, the COD value in lake water decreased slightly, but remained similar. At $30 \mathrm{~d}$, the COD value in lake water was lowest, with the minimal value of 5.13 $\mathrm{mg} / \mathrm{L}$ and the relative reduction of $81.89 \%$ comparing to

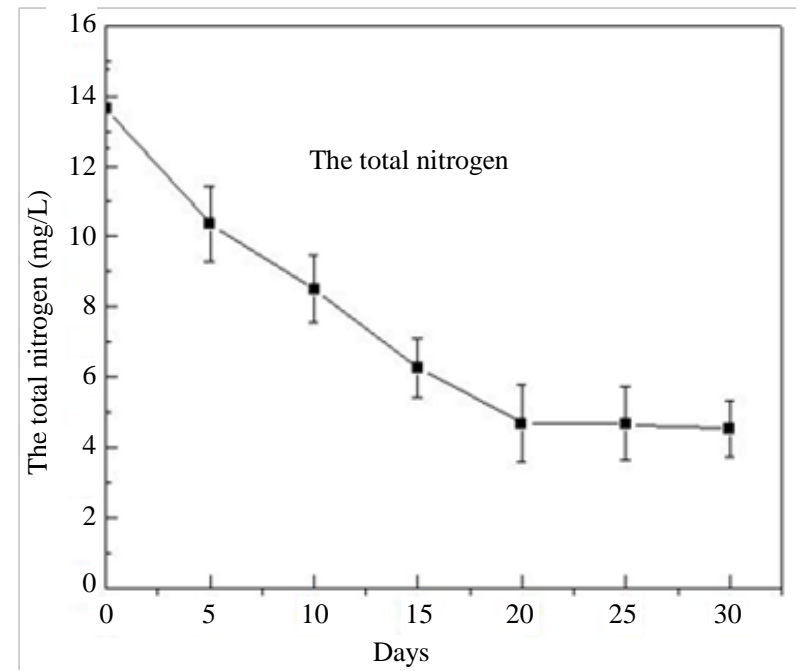

Figure 3. The complex agent effect to total nitrogen of lake water.

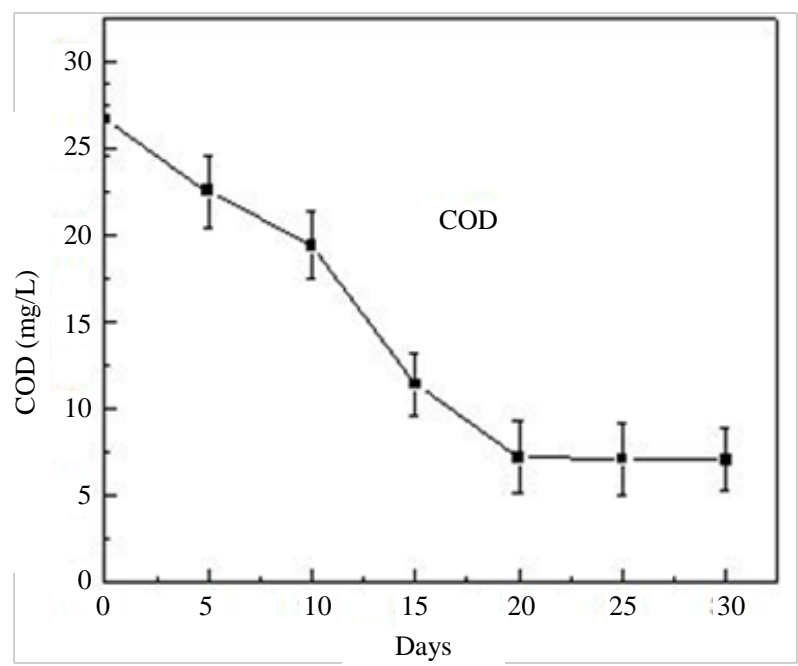

Figure 4. The complex agent effect to COD of lake water. no complex agents control, indicating that addition of complex agent in this ratio can effectively reduce the COD value in lake water.

\section{Conclusion}

Eutrophication can cause deteriorated water quality and reduced level of dissolved oxygen in water, which affected the living of water creatures. Application of microorganisms for water purification and restoration can effectively purify water. Through the screening of bacteria with water restoration and purification capacity showed that Bacillus subtilis had strongest water purification ability, and other bacteria had different levels of impacts on water purification and restoration. Using L1873 orthogonal experimental design to optimize the ratio of complex agents, we got the optimal ratio of each bacteria was: $10 \mathrm{~g} / \mathrm{L}$ Bacillus subtilis, $2 \mathrm{~g} / \mathrm{L}$ photosynthetic bacteria, $0.8 \mathrm{~g} / \mathrm{L}$ lactobacillus, $0.6 \mathrm{~g} / \mathrm{L}$ nitrifying bacteria $1,0.4$ $\mathrm{g} / \mathrm{L}$ nitrifying bacteria 2 and $0.6 \mathrm{~g} / \mathrm{L}$ oligotrophic bacteria. When lake water was purified for $30 \mathrm{~d}$ under this ratio, total phosphorus content decreased $85.90 \%$, total nitrogen content decreased $70.96 \%$, and COD value decreased 81.19\%. These indicated that complex agent in this ratio can effectively reduce the total phosphorus, total nitrogen and COD value in lake water with good purification effect on lake water.

\section{REFERENCES}

[1] Z. Liu, W. L. Kingery and D. H. Huddleston, “Assessment of Water Quality Conditions in the St. Louis Bay Watershed," Journal of Environmental Science and Health, Part A. Toxic/Hazardous Substances and Environmental Engineering, Vol. 43, No. 5, 2008, pp. 468-477. http://dx.doi.org/10.1080/10934520701796283

[2] J. A. Dittman, C. T. Drisco ll and P. M. Groffman, "Dynamics of Nitrogen and Dissolved Organic Carbon at the Hubbar d Brook Experimental Forest,” Ecology, Vol. 88, No. 5, 2007, pp. 1153-1166. http://dx.doi.org/10.1890/06-0834

[3] A. Pecharaply, A. P. Annachhatre and A. P. Parkpian, "Influence of Anaerobic Co-digestion of Sewage and Brewery Sludges on Biogas Production and Sludge Quality,” Journal of Environmental Science and Health, Part A. Toxic/Hazardous Substances and Environmental Engineering, Vol. 42, No. 7, 2007, pp. 911-923.

[4] C. T. Frijters, M. Silvius and J. Fischer, “Applications for Both COD and Nutrient Removal in a CIRCOX Airlift Reactor," Water Science and Technology, Vol. 55, No. 8-9, 2007, pp. 107-114. http://dx.doi.org/10.2166/wst.2007.248

[5] S. T. Lee, "Biodegration of Pyridine by Freely and Suspended Immobilized Pimelobacter,” Applied Microbiology and Biotechnology, Vol. 41, No. 6, 1994, pp. 652-657. http://dx.doi.org/10.1007/BF00167280 